\title{
Autolized Specimen
}

National Cancer Institute

\section{Source}

National Cancer Institute. Autolized Specimen. NCI Thesaurus. Code C78725.

A specimen that has undergone autolysis, or self-digestion by the specimen's own digestive enzymes. 